\title{
Transfer of diazotrophic nitrogen to mesozooplankton in Kiel Fjord, Western Baltic Sea: a mesocosm study
}

\author{
Frank Sommer ${ }^{1,2, *}$, Thomas Hansen ${ }^{1}$, Ulrich Sommer ${ }^{1}$ \\ ${ }^{1}$ Leibniz-Institute for Marine Sciences, Marine Ecology, Düsternbrooker Weg 20, 24105 Kiel, Germany \\ ${ }^{2}$ Danish Institute for Fisheries Research, Marine Ecology and Aquaculture, Kavalergården 6, 2920 Charlottenlund, Denmark
}

\begin{abstract}
In a mesocosm experiment in Kiel Fjord, the plankton community $<250 \mu \mathrm{m}$ was exposed to a mesozooplankton density gradient ( 5 to 80 individuals $\mathrm{l}^{-1}$ ) dominated by the calanoid copepod Acartia clausi. Over the experimental period $(9 \mathrm{~d})$, the diazotrophic cyanobacterium Nodularia spumigena increased exponentially, irrespective of mesozooplankton densities, attaining maximum concentrations of 1200 cells ml $^{-1}$ (3700 filaments $\mathrm{l}^{-1}$ ). At the end of the experiment, the $\delta^{15} \mathrm{~N}$ of particulate organic matter was negatively correlated with $N$. spumigena concentrations, indicating the fixation of isotopically 'light', diazotrophic nitrogen. In all treatments, final copepod $\delta^{15} \mathrm{~N}$ were lower $\left(-0.7\right.$ to $-2.7 \%$ ) than initial copepod $\delta^{15} \mathrm{~N}$, indicating the transfer of diazotrophic nitrogen to mesozooplankton. Based on a simple isotopic mixing model, diazotrophic nitrogen was calculated to contribute 45 to $6 \%$ to final copepod $\delta^{15} \mathrm{~N}$ along the mesozooplankton gradient. This translates to a transfer of 2 to $24 \%$ of net nitrogen fixation to the mesozooplankton standing stock. The absence of any mesozooplankton impact on $N$. spumigena, and the negative impact found for other microplankton, including diatoms and ciliates, suggest that diazotrophically fixed nitrogen reached mesozooplankton indirectly through trophic vectors. This is consistent with the fact that copepod $\delta^{15} \mathrm{~N}$ decreased with decreasing mesozooplankton densities, since only a quantitatively limited dietary source may be expected to result in density-dependent changes in copepod $\delta^{15} \mathrm{~N}$. Considering that natural mesozooplankton densities in the Baltic Sea rarely exceed 10 ind. $\mathrm{l}^{-1}$, the contribution of diazotrophically fixed nitrogen to mesozooplankton may be substantial (23 to $45 \%$ ) during summer blooms of diazotrophic cyanobacteria.
\end{abstract}

KEY WORDS: Diazotrophic cyanobacteria $\cdot$ Nitrogen $\cdot$ Nodularia spumigena $\cdot$ Stable isotopes

\section{INTRODUCTION}

Blooms of diazotrophic cyanobacteria occur in warm, stratified surface layers of lakes and seas (Sellner 1997). Their occurrence is generally explained by the ability of diazotrophic cyanobacteria to fix atmospheric nitrogen $(\mathrm{N})$, which enables cell growth when other sources of aqueous $\mathrm{N}$ are exhausted (Howarth \& Marino 1988). Biogeochemically, diazotrophic cyanobacteria are of considerable interest, because they introduce substantial amounts of new, diazotrophically fixed $\mathrm{N}$ to aquatic systems, thus playing an important role in global nutrient cycles (Redfield 1958). Estimated daily fixation rates lie in the order of $\sim 0.1$ to
$0.3 \mathrm{mmol} \mathrm{N} \mathrm{m}{ }^{-2} \mathrm{~d}^{-1}$ in subtropical oceans (Carpenter \& Romans 1991, Karl et al. 1997), which are attributed largely to blooms of the genus Trichodesmium. In the Baltic Sea, blooms of Nodularia spumigena, Anabaena sp. and Aphanizomenon sp. may introduce even larger amounts of new, diazotrophically fixed N ( 0.1 to $11 \mathrm{mmol} \mathrm{N} \mathrm{m}{ }^{-2} \mathrm{~d}^{-1}$; Larsson et al. 2001, and references therein).

Diazotrophically fixed $\mathrm{N}$ is believed to remain largely in the upper pelagic zone, fuelling up to half of the new production (Karl et al. 1997). This is possible, because most diazotrophic cyanobacteria regulate their buoyancy via gas vesicles, which remain intact even after death (Hoppe 1981), and thus prevent the 
vertical export of diazotrophic $\mathrm{N}$ during stages of decay. Measurements of $\mathrm{N}$ stable isotopes $\left(\delta^{15} \mathrm{~N}\right)$ show that diazotrophically fixed $\mathrm{N}$, which is isotopically 'light' because of the fixation of atmospheric dinitrogen (whose $\delta^{15} \mathrm{~N}$ by definition is $0 \%$ ), is rapidly transferred from microplankton to higher trophic levels (Rolff 2000). Hence, pelagic food webs in which diazotrophic cyanobacteria proliferate contrast isotopically with food webs lacking diazotrophs, where the $\delta^{15} \mathrm{~N}$ of non-diazotrophic phytoplankton is normally higher (5 to $15 \%$; Owens 1987).

The decrease in mesozooplankton $\delta^{15} \mathrm{~N}$ in the presence of diazotrophic cyanobacteria is often believed to indicate direct grazing by mesozooplankton (MeyerHarms et al. 1999, Montoya et al.2002). While this may be common in subtropical seas, where intense feeding by harpacticoid copepods on Trichodesmium spp. filaments has been observed (O'Neil et al. 1996), most studies in the Baltic Sea show dietary avoidance of Nodularia spumigena by mesozooplankton (Sellner et al. 1994, 1996, Engström et al. 2000). This is believed to be associated with the generally poor food quality of cyanobacteria (Ahlgren et al. 1992) and/or the production of the hepatotoxin nodularin by $N$. spumigena (Sellner 1997). The reasons for occasional observations of active mesozooplankton feeding on $N$. spumigena (Kozlowsky-Suzuki et al. 2003) have been associated with aging, since aged filaments reduce toxin production (Carmichael 1994, Sellner 1997) and, at the same time, become 'nutritionally upgraded' by the development of a dense epizootic coating (Hoppe 1981).

Diazotrophic N may, however, also reach mesozooplankton indirectly via 2 interlinked pathways: (1) the release of ammonia and dissolved organic nitrogen (DON) during N fixation (Letelier \& Karl 1996) and its subsequent uptake by phytoplankton or bacteria, and (2) through mesozooplankton grazing on members of the microbial loop that feed directly on cyanobacteria. These pathways are linked to the extent that trophic interactions and nutrient uptake dynamics are shared through plasticity in feeding (i.e. omnivory and mixotrophy; Fenchel 1988) and nutrient uptake (Zehr \& Ward 2002).

In this study, we established a density gradient of mesozooplankton during the onset of a Nodularia spumigena bloom in Kiel Fjord. The aims of the study were to (1) assess the development and potential impact of mesozooplankton on $N$. spumigena and other components of the food web, (2) estimate the import of diazotrophically fixed new N, and (3) quantify its transfer to mesozooplankton. Our results indicate that diazotrophically fixed $\mathrm{N}$ reaches mesozooplankton indirectly through trophic vectors and, considering natural mesozooplankton densities in the Baltic Sea, may contribute substantially to mesozooplankton N content.

\section{MATERIALS AND METHODS}

The study was performed in Kiel Fjord from 4 to 13 September 2002. Salinity and water temperatures were $13 \mathrm{psu}$ and $\sim 20^{\circ} \mathrm{C}$, respectively. Inorganic dissolved nitrogenous (DIN) and phosphorous (DIP) nutrients were present at low ratios (DIN:DIP < 2:1).

The mesocosm bags $\left(\sim 1.2 \mathrm{~m}^{-3}, 1 \times 2 \mathrm{~m}\right)$ were filled by hauling the submerged bags from $\sim 2 \mathrm{~m}$ depth to the surface. After filling, mesozooplankton densities within the bags were reduced to $<3$ ind. $\mathrm{l}^{-1}$ with a $250 \mu \mathrm{m}$ plankton net. At the same time, mesozooplankton, which was numerically dominated ( 80 to $90 \%$ ) by the calanoid copepod Acartia clausi, was collected with a $250 \mu \mathrm{m}$ plankton net and concentrated in a barrel $\left(0.2 \mathrm{~m}^{-3}\right)$. After removal of dead individuals from the bottom of the barrel, mesozooplankton was added to 10 bags ( 5 treatments $\times 2$ replicates) at nominal copepod densities of 5,10, 20, 40 and 80 ind. $\mathrm{l}^{-1}$. The highest density was chosen to surpass 2-fold maximum copepod densities observed in Kiel Bight (Behrends 1996). An additional 2 bags (control) received no mesozooplankton, resulting in a total of 12 bags. The bags were covered with transparent polyethylene foil mounted in frames to protect bag contents from bird faeces.

Phytoplankton and ciliate concentrations were determined from samples fixed with a few drops of Lugol's solution, following Utermöhl (1958). Nodularia spumigena specific growth rates $(\mu)$ were calculated as $\mu\left(\mathrm{d}^{-1}\right)=\ln \left[\left(\text { cells ml }{ }^{-1}\right)_{a} /\left(\text { cells } \mathrm{ml}^{-1}\right)_{b}\right] / C$, where $a$ and $b$ are the concentrations on the final and initial day, respectively, and $c$ the total number of days. Carbon (C) biomass was calculated from microscopically determined cell length estimates using a conversion factor of $0.11 \mathrm{pg} \mathrm{C} \mu \mathrm{m}^{-3}$ (Larsson et al. 2001). Copepod densities were determined from samples collected with a $50 \mu \mathrm{m}$ plankton net and preserved in $4 \%$ formalin.

The impact of mesozooplankton on phytoplankton and ciliates was measured by the coefficient $b$ in the regression model $y=a x^{b}$, where $y$ is the cell concentration on the final day of the experiment and $x$ is nominal copepod density. According to the sign of the regression slope $(b)$, copepods were assigned a positive or negative impact on the respective food particle (see also Sommer et al. 2001). It should be noted that the coefficient $b$ includes the combined effects of direct grazing, grazing on trophic intermediates, and nutrient regeneration. Data from $1 \mathrm{bag}$ (10 ind. $\mathrm{l}^{-1}$ treatment) was excluded from all analyses because of likely contamination with bird faeces.

The $\mathrm{N}$ content of particulate organic matter $<64 \mu \mathrm{m}$ $\left(\mathrm{PON}_{\mathrm{P}}\right)$ was determined from $<64 \mu \mathrm{m}$ pre-screened samples $(500 \mathrm{ml})$ in a Fisons-1500N CHN-analyser. Dissolved inorganic N (DIN) and total $\mathrm{N}^{*}\left(\mathrm{TN}^{*}\right)$ was 
determined from unscreened $10 \mathrm{ml}$ samples in a Scalar SAN ${ }^{\text {plus }}$ autoanalyser. Dissolved organic N (DON) was calculated by subtracting $\mathrm{PON}_{\mathrm{P}}$ and DIN from TN*. Mesozooplankton $\mathrm{N}$ content $\left(\mathrm{PON}_{\mathrm{Z}}\right)$ was estimated from copepod densities assuming $0.4 \mu \mathrm{g} \mathrm{N}$ ind. $^{-1}$ (Mauchline 1998). $\mathrm{PON}_{\mathrm{P}}$ and $\mathrm{PON}_{\mathrm{Z}}$ were added to give $\mathrm{PON}_{\mathrm{P}+\mathrm{Z}}$. The increase in total $\mathrm{N}$ over the experimental period $\left(\Delta \mathrm{TN}_{t}\right)$ was calculated as $\Delta \mathrm{TN}_{t}=\Sigma\left(X_{a}-X_{b}\right)$, where $X$ is DIN, DON or $\mathrm{PON}_{\mathrm{P}+\mathrm{Z}}$, and $a$ and $b$ are the respective $\mathrm{N}$ concentrations $\left(\mu \mathrm{mol} \mathrm{l}^{-1}\right)$ on the final and initial days, respectively. This was done instead of using direct measurements of $\mathrm{TN}^{*}$ because the low (10 ml) sample volumes of $\mathrm{TN}^{*}$ were likely to underestimate the contributions of $\mathrm{PON}_{\mathrm{P}}$ and $\mathrm{PON}_{\mathrm{Z}}$ to total $\mathrm{N}$. $\Delta \mathrm{TN}_{t}$ was corrected for minimum and maximum estimates of atmospheric $\mathrm{N}$ deposition (0 and $1300 \mathrm{mg} \mathrm{N}$ $\mathrm{m}^{-2} \mathrm{yr}^{-1}$, respectively; Lindfors et al. 1993) on the basis of surface area $\left(0.79 \mathrm{~m}^{2}\right)$ and volume $\left(\sim 1.2 \mathrm{~m}^{-3}\right)$ of the mesocosm bags, giving the minimum and maximum estimates of net $\mathrm{N}$ fixation $\left(\mathrm{N}_{\text {fixed }}\right)$.

The $\delta^{15} \mathrm{~N}$ of POM was determined from $<64 \mu \mathrm{m}$ prescreened samples $(250 \mathrm{ml})$ collected in situ at the start of the experiment $(\mathrm{n}=4)$ and in each bag at the end of the experiment. Copepod $\delta^{15} \mathrm{~N}$ was determined from mesozooplankton samples collected in the barrel, in which mesozooplankton were initially concentrated ( $\mathrm{n}=4$ ), and in each bag at the end of the experiment. Mesozooplankton samples were preserved in 90\% ethanol to allow for species/stage separation. Each measurement of copepod $\delta^{15} \mathrm{~N}$ consisted of 40 pooled adult Acartia clausi. All $\delta^{15} \mathrm{~N}$ samples were measured with a precision of $\pm 0.2 \%$ in a Finnigan Delta Plus mass spectrometer after combustion in a Fisons-1500N $\mathrm{CHN}$-analyser. The $\delta^{15} \mathrm{~N}$ was calculated as $\delta^{15} \mathrm{~N}[\%$ ] $=$ $\left[\left(R_{\text {sample }} / R_{\text {standard }}\right)-1\right] \times 1000$, where $R$ is the ratio ${ }^{15} \mathrm{~N}:{ }^{14} \mathrm{~N}$, and the standard is atmospheric dinitrogen.

The contribution of diazotrophically derived $\mathrm{N}$ to mesozooplankton $\delta^{15} \mathrm{~N}\left(\% \mathrm{~N}_{\mathrm{Z} \text {-diazo }}\right.$ ) was calculated from a simple 2-source isotopic mixing model modified from Kaehler et al. (2000). The mixing model used diazotrophic $\mathrm{N}$ and copepod $\mathrm{N}$ at the start of the experiment as the 2 'sources' contributing to copepod $\mathrm{N}$ at the end of the experiment. $\mathrm{N}$ of trophic intermediates was not considered, because copepods were assumed to be in 'isotopic balance' with their (non-diazotrophic) food sources at the onset of the experiment. This was based on the observation that the $\delta^{15} \mathrm{~N}$ of copepods $(9.9 \pm 0.2 \%)$ and POM $(5.9 \pm 0.2 \%)$ were separated by $\sim 1$ trophic level (i.e. 4\%: Deniro \& Epstein 1981, Minagawa \& Wada 1984) at the start of the experiment, when cyanobacterial concentrations were negligible. Thus, we assumed that continued grazing (plus $4 \%$ trophic enrichment) in the absence of diazotrophic cyanobacteria would have resulted in unaltered copepod $\delta^{15} \mathrm{~N}$ over time. Since the extent of trophic enrich- ment of diazotrophically derived $\mathrm{N}$ was unknown, $\% \mathrm{~N}_{\text {Z-diazo }}$ was calculated both with and without the observed net trophic enrichment (TE) of $4 \%$. Accordingly, the minimum and maximum estimates of $\% \mathrm{~N}_{\mathrm{Z} \text {-diazo }}$ were calculated as $\% \mathrm{~N}_{\mathrm{Z} \text {-diazo }}=100 \times\left(\delta^{15} \mathrm{~N}_{\mathrm{Z} \text {-final }}\right.$ $\left.-\delta^{15} N_{Z \text {-initial }}\right) /\left(T E+\delta^{15} N_{\text {diazo }}-\delta^{15} N_{Z \text {-initial }}\right)$, where $\delta^{15} N_{Z \text { - }}$ final and $\delta^{15} \mathrm{~N}_{\mathrm{Z} \text {-initial }}$ are copepod $\delta^{15} \mathrm{~N}$ on the final and initial days, respectively, $\delta^{15} \mathrm{~N}_{\text {diazo }}$ is the $\delta^{15} \mathrm{~N}$ of diazotrophic $\mathrm{N}$ (assumed to be $0 \%$ ), and TE is trophic enrichment ( 0 or $+4 \%$, respectively).

The portion of diazotrophically fixed $\mathrm{N}$ transferred to the standing stock of mesozooplankton at the end of the experiment ( $\left.\% \mathrm{~N}_{\text {transfer}}\right)$ was calculated for 2 extreme scenarios: (1) the combination of maximum estimates of diazotrophically derived $\mathrm{N}$ in mesozooplankton $\left(\% \mathrm{~N}_{\mathrm{Z} \text {-diazo }}\right)$ and minimum estimates of net $\mathrm{N}$ fixation $\left(\mathrm{N}_{\text {fixed }}\right)$, and (2) the combination of minimum $\% \mathrm{~N}_{\mathrm{Z} \text {-diazo }}$ and maximum $\mathrm{N}_{\text {fixed }}$. Accordingly, $\% \mathrm{~N}_{\text {transfer }}$ was calculated as $\% \mathrm{~N}_{\text {transfer }}=\% \mathrm{~N}_{\mathrm{Z} \text {-diazo }} \times D / \mathrm{N}_{\text {fixed }}$, where $\% \mathrm{~N}_{\mathrm{Z} \text {-diazo }}$ is the contribution of diazotrophic $\mathrm{N}$ to mesozooplankton, $D$ is copepod density at the end of the experiment (in $\mu \mathrm{mol} \mathrm{N} \mathrm{l}^{-1}$, assuming $0.4 \mu \mathrm{g} \mathrm{N}$ ind. ${ }^{-1}$; Mauchline 1998), and $\mathrm{N}_{\text {fixed }}$ is net $\mathrm{N}$ fixation (in $\mu \mathrm{mol} \mathrm{l}^{-1}$ ), respectively.

Regression analyses were performed using SigmaPlot 8.0 software.

\section{RESULTS}

Nodularia spumigena increased exponentially in all bags from initially $<40$ cells $\mathrm{ml}^{-1}$ to $\sim 80-1200$ cells ml ${ }^{-1}$ at the end of the experiment (Fig. 1A). This translates to estimated specific growth rates of 0.2 to $0.6 \mathrm{~d}^{-1}$, and an increase in biomass of 0.07 to $1.1 \mathrm{mmol} \mathrm{C} \mathrm{m}^{-3}$. On all days, $N$. spumigena cells appeared microscopically 'healthy', with rigid cell walls and an even, rich coloration. N. spumigena filament concentrations increased similarly from initially $<200$ filaments $\mathrm{l}^{-1}$ to a maximum of 3700 filaments $\mathrm{l}^{-1}$ at the end of the experiment (Fig. 1B). This was accompanied by increases in filament length from initially $<1 \mathrm{~mm}$ to $\sim 7-10 \mathrm{~mm}$ at the end of the experiment (not shown). Besides N. spumigena, no other diazotrophic cyanobacterium was present.

Mesozooplankton, which was numerically dominated ( 80 to $90 \%$ ) by Acartia clausi, had no significant impact on Nodularia spumigena cell concentrations (Table 1). Similarly, no significant impact was found for 3 out of 4 dinoflagellate species. For the 4 th species, Prorocentrum micans, a low, significantly negative impact $(-0.58)$ was found. The impact on diatom species was in all cases significant, yet with opposing signs. While the impact was positive for both Dactyliosolen fragilissimus (+1.45) and Pseudonitzschia sp. 


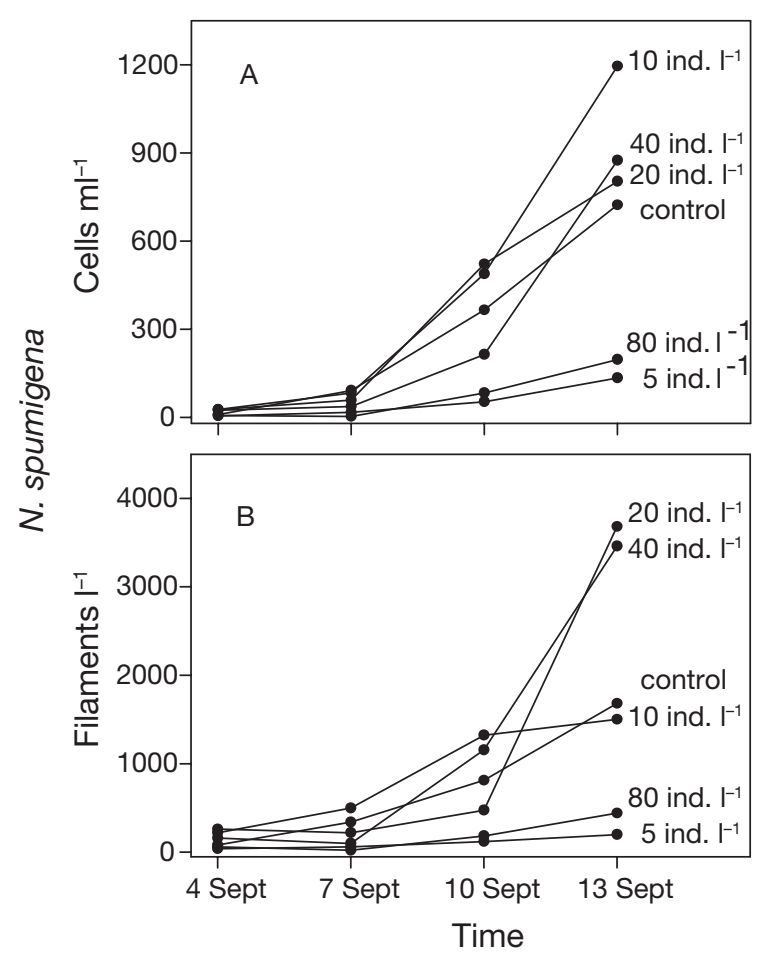

Fig. 1. Nodularia spumigena. Development of (A) cell concentrations and (B) filament concentrations in mesocosm bags. Densities are nominal copepod densities. For clarity, only 1 replicate of each treatment is shown

$(+0.44)$ (i.e. these species increased numerically with increasing copepod density), the impact was negative (-2.05) for Ditylum brightwellii. A significantly negative impact, which was also quantitatively the strongest $(-5.57)$, was found for heterotrophic ciliates. Correlations of ciliate concentrations with concentrations of $D$. fragilissimus and Pseudonitzschia sp.

Table 1. Mesozooplankton impact on phytoplankton and ciliate concentrations measured by coefficient $b$ in regression model $y=a x^{b}$, where $y$ is cell concentration on final day and $x$ is nominal copepod density. ns: not significant; ${ }^{*} \mathrm{p}<0.05$;

$$
{ }^{* *} \mathrm{p}<0.01 i^{* * *} \mathrm{p}<0.0001
$$

\begin{tabular}{|c|c|c|c|c|}
\hline Taxon & a & $b$ & $\mathrm{r}^{2}$ & $\mathrm{p}$ \\
\hline \multicolumn{5}{|l|}{ Cyanobacteria } \\
\hline Nodularia spumigena & 1400 & -0.28 & $<0.01$ & $0.42^{\mathrm{ns}}$ \\
\hline \multicolumn{5}{|l|}{ Dinoflagellates } \\
\hline Ceratium fusus & 1.2 & -0.06 & $<0.01$ & $0.84^{\mathrm{ns}}$ \\
\hline Ceratium tripos & 3.6 & -1.17 & 0.09 & $0.19^{\text {ns }}$ \\
\hline Prorocentrum minimum & 17 & -0.36 & 0.06 & $0.48^{\mathrm{ns}}$ \\
\hline Prorocentrum micans & 7.5 & -0.58 & 0.32 & $0.03^{*}$ \\
\hline \multicolumn{5}{|l|}{ Diatoms } \\
\hline Dactyliosolen fragilissimus & 10 & +1.45 & 0.77 & $0.0002^{* * *}$ \\
\hline Pseudonitzschia sp. & 2428 & +0.44 & 0.72 & $0.0009^{* * *}$ \\
\hline Ditylum brightwellii & 1788 & -2.05 & 0.38 & $0.03^{*}$ \\
\hline \multicolumn{5}{|l|}{ Ciliates } \\
\hline Strombidium sp. & 53 & -5.57 & 0.61 & $0.004^{* *}$ \\
\hline
\end{tabular}

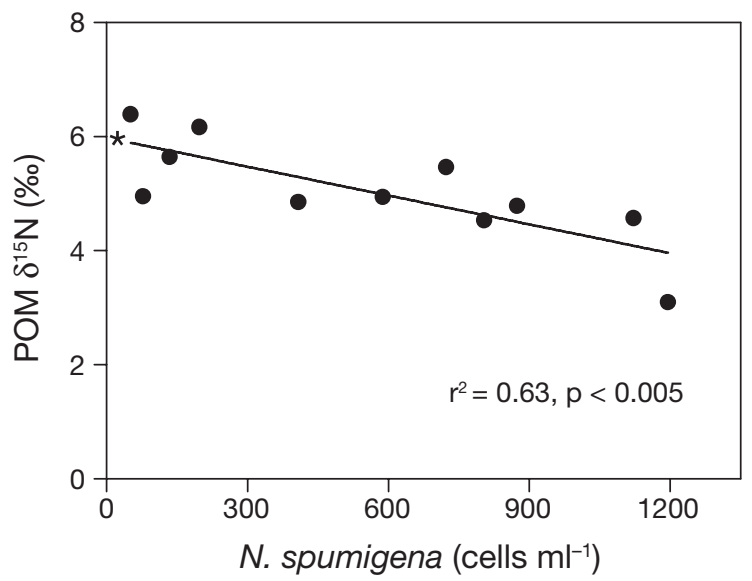

Fig. 2. Nodularia spumigena. POM $\delta^{15} \mathrm{~N}$ as a function of cell concentrations on final day of the experiment. Asterisk designates POM $\delta^{15} \mathrm{~N}$ at start of experiment $(5.9 \pm 0.2 \%$, $\mathrm{n}=4)$, when $N$. spumigena concentrations were $<40$ cells $\mathrm{ml}^{-1}$. Regression is $y=6.0-0.0017 x$

were not significant ( $p>0.2)$, indicating that the increase in these diatom species was unlikely to be the result of a trophic cascade of 'copepods-ciliatesdiatoms'.

On the final day of the experiment, the $\delta^{15} \mathrm{~N}$ of POM was significantly negatively correlated with increasing concentrations of Nodularia spumigena (Fig. 2). In bags, where final $N$. spumigena concentrations were similarly low $\left(<100\right.$ cells $\left.\mathrm{ml}^{-1}\right)$, as at the start of the experiment $\left(<40\right.$ cells $\left.\mathrm{ml}^{-1}\right)$, final POM $\delta^{15} \mathrm{~N}$ was within the range of the initial POM $\delta^{15} \mathrm{~N}(5.9 \pm 0.3 \%$; $\mathrm{n}=4)$. The lowest $\delta^{15} \mathrm{~N}$ of POM (3.1\%) was found in the bag of highest $N$. spumigena concentrations (1200 cells ml-1).

The $\delta^{15} \mathrm{~N}$ of Acartia clausi was significantly positively correlated with copepod density at the end of the experiment (Fig. 3). The data suggest an exponential decrease in copepod $\delta^{15} \mathrm{~N}$ with decreasing density. Final $\delta^{15} \mathrm{~N}$ of $A$. clausi were in all cases lower than the $\delta^{15} \mathrm{~N}$ at the start of the experiment $(9.9 \pm 0.2 \%$; $\mathrm{n}=$ $4)$. The isotopic decrease in final copepod $\delta^{15} \mathrm{~N}$ with respect to the initial $\delta^{15} \mathrm{~N}$ ranged from -2.7 to $-0.7 \%$. The difference between the initial $\delta^{15} \mathrm{~N}$ of POM (Fig. 2) and the initial $\delta^{15} \mathrm{~N}$ of $A$. clausi (Fig. 3) at the start of the experiment was $+4.0 \%$, i.e. approximately 1 trophic level.

The increase in total $\mathrm{N}$ over the experimental period $\left(\Delta \mathrm{TN}_{t}\right)$ ranged from 1.8 to $7.8 \mu \mathrm{mol} \mathrm{l}^{-1}$ (Fig. 4A). This corresponds to a 9 to $25 \%$ increase in total $\mathrm{N}$ with respect to the concentrations at the start of the experiment (20

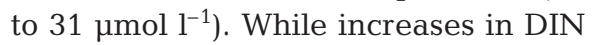




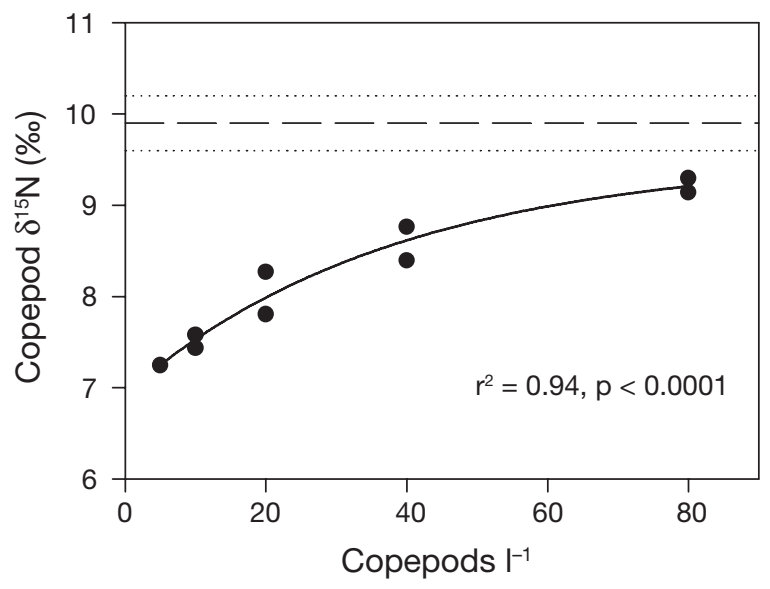

Fig. 3. Copepod $\delta^{15} \mathrm{~N}$ on final day of experiment as a function of nominal copepod density. Dashed and dotted horizontal lines represent mean $\pm 95 \%$ confidence intervals of initial $\delta^{15} \mathrm{~N}(9.9 \pm 0.2 \%$, $\mathrm{n}=4)$, respectively. Regression is $y=9.6-2.6 \mathrm{e}^{-0.026 x}$
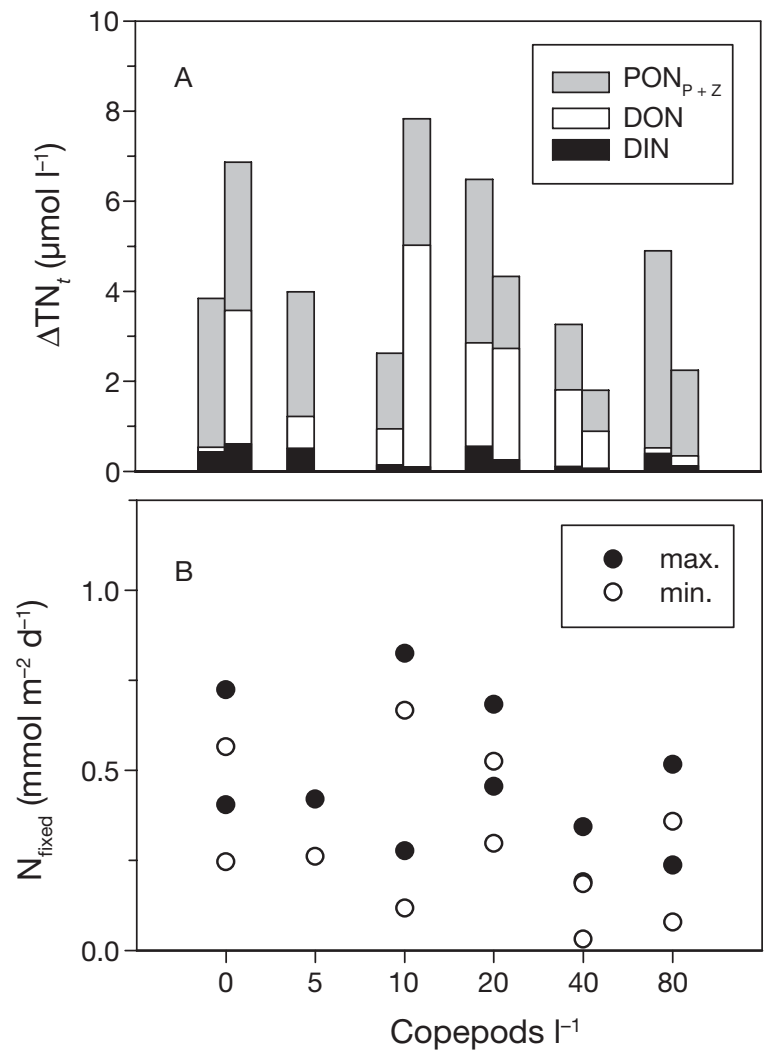

Fig. 4. (A) Increase in total $\mathrm{N}$ over experimental period $\left(\Delta \mathrm{TN}_{t}\right)$ and (B) estimates of net $\mathrm{N}$ fixation $\left(\mathrm{N}_{\text {fixed }}\right)$ as a function of nominal copepod density. $\mathrm{PON}_{\mathrm{P}+\mathrm{z}}$ comprises $<64 \mu \mathrm{m}$ prescreened PON and mesozooplankton PON. Filled and empty symbols refer to maximum and minimum estimates of $\mathrm{N}_{\text {fixed }}$, respectively. Note categorical scaling of abscissa. Treatments in duplicate were relatively low $\left(<0.6 \mu \mathrm{mol} \mathrm{\textrm {l } ^ { - 1 }}\right)$, increases in both DON (0.1 to $5.0 \mathrm{mmol} \mathrm{l}^{-1}$ ) and $\mathrm{PON}_{\mathrm{P}+\mathrm{Z}}$ (0.9 to $4.4 \mu \mathrm{mol}$ $\mathrm{l}^{-1}$ ) were more pronounced but also more variable. The relative contribution of changes in DIN, DON and $\mathrm{PON}_{\mathrm{P}+\mathrm{Z}}$ with respect to $\Delta \mathrm{TN}_{t}$ was $\sim 1$ to 13,3 to 65 and 36 to $89 \%$, respectively. In none of the cases was a correlation apparent with nominal copepod density or with mean and final Nodularia spumigena concentrations (linear and/or power regressions: $p>0.2$; not shown). $\Delta \mathrm{TN}_{t}$ corrected for minimum and maximum estimates of atmospheric $\mathrm{N}$ deposition in the Baltic Sea corresponded to an estimated net $\mathrm{N}$ fixation $\left(\mathrm{N}_{\text {fixed }}\right)$ of 0.3 to $7.4 \mathrm{mmol} \mathrm{N} \mathrm{m}^{-2}$ within the experimental period (9 d) or, accordingly, to minimum and maximum daily net fixation rates of 0.03 to $0.7 \mathrm{mmol} \mathrm{N} \mathrm{m}^{-2}$ and 0.2 to $0.8 \mathrm{mmol} \mathrm{N} \mathrm{m}^{-2}$, respectively (Fig. 4B).

Based on our isotopic mixing model, the contribution of diazotrophically derived $\mathrm{N}$ to final mesozooplankton $\delta^{15} \mathrm{~N}$ ( $\% \mathrm{~N}_{\mathrm{Z} \text {-diazo }}$ ) ranged from 45 to $10 \%$ (maximum estimates) and 26 to $6 \%$ (minimum estimates) (Fig. 5A).
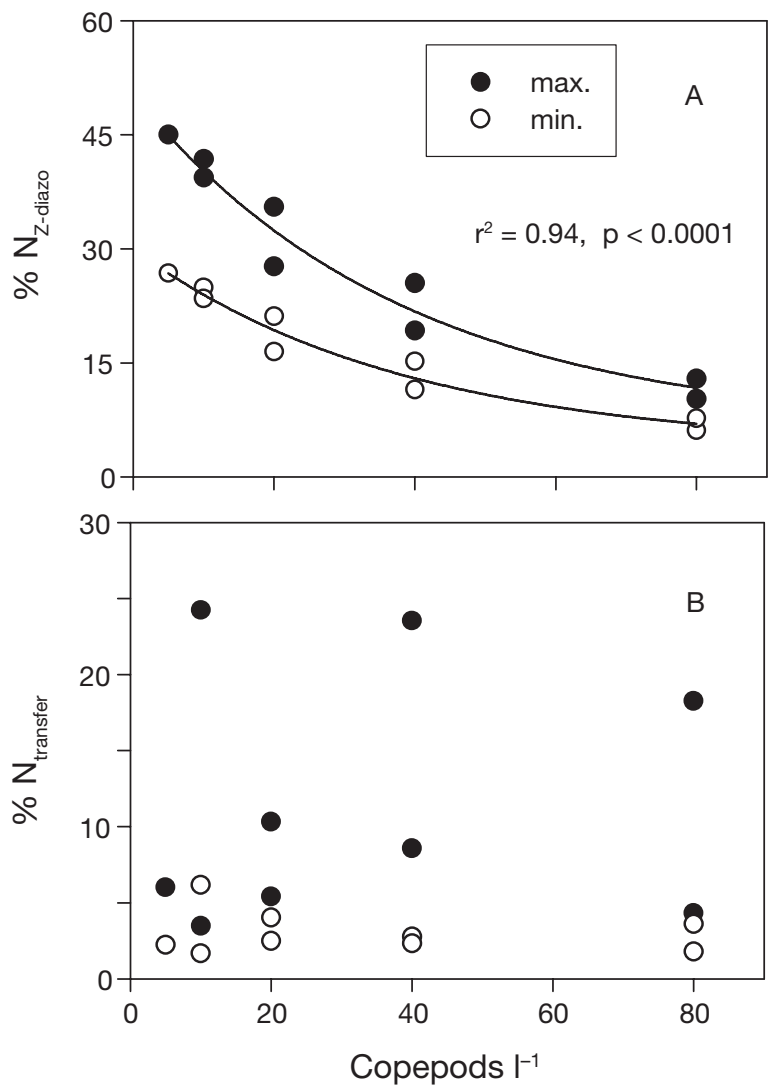

Fig. 5. (A) Contribution of diazotrophically derived $\mathrm{N}$ to mesozooplankton $\delta^{15} \mathrm{~N}\left(\% \mathrm{~N}_{\text {Z-diazo }}\right)$ and (B) portion of net $\mathrm{N}$ fixation transferred to standing stock of mesozooplankton at end of experiment ( $\left.\% \mathrm{~N}_{\text {transfer }}\right)$ as a function of nominal copepod density. Filled and empty symbols refer to maximum and minimum estimates, respectively. Regressions on maximum and minimum estimates of $\% \mathrm{~N}_{\mathrm{Z} \text {-diazo }}$ are $y=6.3+44 \mathrm{e}^{-0.026 x}$ and $y=3.8+26 \mathrm{e}^{-0.026 x}$, respectively. Treatments in duplicate 
Values of \% $\mathrm{N}_{\mathrm{Z} \text {-diazo }}$ decreased exponentially with increasing copepod density, similar to the exponential increase in copepod $\delta^{15} \mathrm{~N}$ with copepod density (Fig. 3), since $\% \mathrm{~N}_{\mathrm{Z} \text {-diazo }}$ was calculated from the latter (see 'Materials and methods'). The portion of diazotrophically fixed $\mathrm{N}$ transferred to the mesozooplankton ( $\% \mathrm{~N}_{\text {transfer }}$ ) was estimated to range from a minimum of 2 to $6 \%$ to a maximum of 3 to $24 \%$ (Fig. 5B). No correlation of $\% \mathrm{~N}_{\text {transfer }}$ estimates with copepod density were evident.

\section{DISCUSSION}

The exponential increase in the diazotrophic cyanobacterium Nodularia spumigena during the course of the experiment was probably triggered by a combination of environmental factors favourable for the development of N. spumigena (Kononen \& Nömmann 1992), i.e. water temperatures were high $\left(\sim 20^{\circ} \mathrm{C}\right)$, ratios of dissolved inorganic nutrients were low (DIN:DIP $<2: 1$ ), and salinities were below $15 \mathrm{psu}$. In particular, the latter has been shown to be a prerequisite for the germination of N. spumigena resting stages (Blackburn et al. 1996). Although N. spumigena attained peak concentrations of 3700 filaments $1^{-1}$, final concentrations were still low compared to 'normal' bloom conditions in the Baltic Proper, where concentrations may be in the order of $\sim 30 \times 10^{6}$ filaments $1^{-1}$ (Sellner et al. 1994). Hence, N. spumigena in our experiment may be seen as still in an early bloom stage.

The microscopically 'healthy' appearance of cells and the high $\left(0.2\right.$ to $\left.0.6 \mathrm{~d}^{-1}\right)$ specific growth rates make it possible that Nodularia spumigena was potentially toxic throughout the experiment, since the production of toxins can be high during exponential growth (Carmichael 1994, Sellner 1997). Therefore, toxicity and/or the generally poor food quality of cyanobacteria (Ahlgren et al. 1992) may have acted as grazing deterrents, resulting in the absence of any mesozooplankton impact on the population dynamics of $N$. spumigena. This is in line with most studies in the Baltic Sea, which show dietary avoidance of diazotrophic cyanobacteria by several mesozooplankton species (Sellner et al. 1994, 1996, Engström et al. 2000, but see Koski et al. 2002).

Our estimates of daily net $\mathrm{N}$ fixation rates $(\sim 0.03$ to $0.8 \mathrm{mmol} \mathrm{N} \mathrm{m}^{-2} \mathrm{~d}^{-1}$ ) are lower than previous estimates for the Baltic Proper using a conceptually similar 'biomass' approach ( 2 to $6 \mathrm{mmol} \mathrm{N} \mathrm{m}^{-2} \mathrm{~d}^{-1}$; Larsson et al. 2001). Our estimates are also at the lower range of $N$ fixation rates determined during summer in the Baltic Proper (0.15 to $2.3 \mathrm{mmol} \mathrm{N} \mathrm{m} \mathrm{N}^{-2} \mathrm{~d}^{-1}$; Wasmund et al. 2005), using 3 different methods to estimate $\mathrm{N}$ fixation. One reason for the fact that our estimates are lower may be that Nodularia spumigena biomass in our experiment was considerably lower $\left(<1.1 \mathrm{mmol} \mathrm{C} \mathrm{m}^{-3}\right)$ than cyanobacterial biomass in the abovementioned studies ( 2.4 and $\sim 60 \mathrm{mmol} \mathrm{C} \mathrm{m}^{-3}$, respectively). In addition, our experiment was characterised by a monospecific bloom of $N$. spumigena, whereas in the other studies $\mathrm{N}$ fixation rates were determined from mixed cyanobacterial blooms, which (in the case of Wasmund et al. 2005) were dominated by Aphanizomenon sp. rather than $N$. spumigena (no taxonomic resolution was reported in Wasmund et al. 2005). As a third factor, we found that the $<64 \mu \mathrm{m}$ pre-screening process of POM (necessary in order to exclude copepod nauplii) visibly retained a fraction of POM on the sieves. Adding additional biomass to our estimates of $\Delta \mathrm{TN}_{t}$ would, of course, increase our estimates of net $\mathrm{N}$ fixation. At all events, our estimates of net $\mathrm{N}$ fixation may be attributed exclusively to diazotrophic $\mathrm{N}$ fixation by $N$. spumigena, since the correlation of POM $\delta^{15} \mathrm{~N}$ with $N$. spumigena concentrations unequivocally demonstrates that the introduction of 'isotopically' light $\mathrm{N}$ to the pelagic system was linked to the proliferation of N. spumigena.

The decrease in final copepod $\delta^{15} \mathrm{~N}$ with respect to initial $\delta^{15} \mathrm{~N}(-2.7$ to $-0.7 \%$ ) shows that diazotrophically fixed $\mathrm{N}$ reached mesozooplankton within the timescale (9 d) of our experiment. Rolff (2000), using a monthly time-scale, reported slightly stronger decreases in mesozooplankton $\delta^{15} \mathrm{~N}(-2$ to $-4 \%$ ) following the formation of cyanobacterial blooms in the Baltic Sea. This indicates that the transfer of diazotrophic nitrogen to mesozooplankton also occurs in situ in quantitatively similar terms when spatial separation of mesozooplankton and positively buoyant cyanobacteria at the sea surface is not impeded, as in our experimental set-up. Although incorporation of diazotrophically fixed $\mathrm{N}$ is nowadays accepted as the reason for the occurrence of low mesozooplankton $\delta^{15} \mathrm{~N}$ (Montoya et al. 2002), an earlier view proposed the excretion and recycling of isotopically depleted ammonia by mesozooplankton (Checkley \& Entzeroth 1985). The fact that POM $\delta^{15} \mathrm{~N}$ in our experiment was not correlated with copepod density but with Nodularia spumigena concentration further supports the presently accepted view.

Based on our estimates of net $\mathrm{N}$ fixation and estimates of the diazotrophic $\mathrm{N}$ contribution to mesozooplankton ( $\% \mathrm{~N}_{\mathrm{Z} \text {-diazo }}$ ), we calculated that a maximum of 3 to $24 \%$ of net $\mathrm{N}$ fixation was transferred to the mesozooplankton standing stock by the end of the experiment. These values are relatively low, demonstrating that the majority of diazotrophically fixed $\mathrm{N}$ is either retained in POM (which, of course, includes Nodularia spumigena itself) or lost to the DON pool (Bronk et al. 1994). In our experiment the latter pool was quantita- 
tively important, representing up to $65 \%$ of $\Delta \mathrm{TN}_{t}$. Our estimates of $\mathrm{N}_{\text {transfer }}$ may however underestimate the true transfer of diazotrophic $\mathrm{N}$ because they are sensitive to the assumptions of our mixing model.

In this model, we assumed that copepods were initially in 'isotopic balance' with their non-diazotrophic food sources, such that feeding (including the incorporation of trophic intermediates) plus net trophic enrichment would result in approximately unaltered copepod $\delta^{15} \mathrm{~N}$ over time. Therefore, we further assumed that copepod $\delta^{15} \mathrm{~N}$ at the end of the experiment would be determined only by the incorporation of diazotrophic $\mathrm{N}$ relative to the $\mathrm{N}$ biomass present in copepods at the start of the experiment. Whether diazotrophic $\mathrm{N}$ reached copepods directly or indirectly via trophic vectors (i.e. ciliates and phytoplankton, which incorporate diazotrophic $\mathrm{N}$ through particulate ingestion and uptake of released ammonia [Letelier \& Karl 1996], respectively) was irrelevant with respect to this assumption. Our third assumption, namely that both $\mathrm{N}$ sources remained isotopically stable over time, was however unlikely to be true, since the entire food web, including all dietary sources and mesozooplankton themselves, may be expected to become increasingly isotopically 'diluted' with time. As a consequence, our estimates of both $\% \mathrm{~N}_{\text {transfer }}$ and $\% \mathrm{~N}_{\mathrm{Z} \text {-diazo }}$ may be considered conservative and are likely to be best represented by our calculated maximum estimates. This applies similarly to the correction of $\Delta \mathrm{TN}_{t}$ by maximum estimates of atmospheric $\mathrm{N}$ deposition, since the mesocosm bags were covered with transparent plastic foil throughout the experiment. A more precise calculation of $\% \mathrm{~N}_{\text {Z-diazo }}$ would obviously require an isotopically dynamic mixing model, higher time-resolution of sampling and, preferably, knowledge of the $\delta^{15} \mathrm{~N}$ of all mesozooplankton dietary items. Considering the complexity of the task, our approach may serve as a rough guide.

The absence of an impact by mesozooplankton on Nodularia spumigena concentrations makes it improbable that diazotrophic $\mathrm{N}$ reached mesozooplankton via a direct grazing link, as sometimes suggested (MeyerHarms et al. 1999, Montoya et al. 2002). Instead, indirect pathways via 1 or several trophic vectors are more likely. The decrease in copepod $\delta^{15} \mathrm{~N}$ with decreasing copepod density supports this view since only a quantitatively limited dietary vector may be expected to result in a density-dependent decrease in copepod $\delta^{15} \mathrm{~N}$ : changes in consumer $\delta^{15} \mathrm{~N}$ will depend on the portion of the incorporated 'new' dietary $\mathrm{N}$ source relative to the consumer's $\mathrm{N}$ biomass beforehand (see also: Sommer et al. 2005). The negative impact found for heterotrophic ciliates, 1 dinoflagellate and 1 diatom species make these taxa probable dietary vectors of diazotrophic $\mathrm{N}$ transfer. Given the high degree of plasticity in nutrient uptake and the various linkages between the 'classical' and 'microbial' food webs through mixotrophic dinoflagellates and ciliates (Fenchel 1988), it will be difficult to estimate their relative contributions here, or elsewhere.

In conclusion, our study has shown that the diazotrophic cyanobacterium Nodularia spumigena increased exponentially over time, irrespective of a strong mesozooplankton density gradient ( 5 to 80 ind. $\left.\mathrm{l}^{-1}\right)$. Diazotrophic net $\mathrm{N}$ fixation $(\sim 0.03$ to $0.8 \mathrm{mmol} \mathrm{N}$ $\mathrm{m}^{-2} \mathrm{~d}^{-1}$ ) was at the lower range of earlier reports, possibly due to the low biomass of $N$. spumigena and the fact that our sieving process removed part of the POM. Decreases in mesozooplankton $\delta^{15} \mathrm{~N}$ over time and with decreasing nominal copepod density suggest that diazotrophically fixed $\mathrm{N}$ reached mesozooplankton indirectly, through trophic vectors such as ciliates and diatoms. Given that natural copepod densities in the Western Baltic Sea rarely exceed 10 ind. $\mathrm{l}^{-1}$ (Behrends 1996), the contribution of diazotrophic $\mathrm{N}$ to copepod biomass (23 to $45 \%$ ) and the portion of net $\mathrm{N}$ fixation transferred to mesozooplankton ( 3 to $24 \%$ ) may be substantial.

Acknowledgements. We thank C. Becker, D. Brepohl, H. Feuchtmayr, R. Gergs, K. Maszassek and R. Melero for zooplankton counting and assistance during field work. We are grateful to J. Feiertag and the personnel of WSA-Lübeck for help and permission to work on the facilities. This study was financially supported by grants to F.S. (Schrödinger-grant J2370-B03, Austrian Science Foundation) and U.S. (SO 145/19-1, German Research Foundation).

\section{LITERATURE CITED}

Ahlgren G, Gustafsson IB, Boberg M (1992) Fatty acid content and chemical composition of freshwater microalgae. J Phycol 28:37-50

Behrends G (1996) Long-term investigation of seasonal mesozooplankton dynamics in Kiel Bight, Germany. Proc 13th Balt Mar Biol Symp 1:93-98

Blackburn SI, McCausland MA, Boch CJ, Newman SJ, Jones GJ (1996) Effect of salinity on growth and toxin production in cultures of the bloom-forming cyanobacterium Nodularia spumigena from Australian waters. Phycologia 35: 511-522

Bronk DA, Gilbert PM, Ward BB (1994) Nitrogen uptake, dissolved organic nitrogen release, and new production. Science 265:1843-1846

Carmichael WW (1994) The toxins of cyanobacteria. Sci Am 270:64-72

Carpenter DJ, Romans K (1991) Major role of the cyanobacterium Trichodesmium in nutrient cycling in the North Atlantic Ocean. Science 254:1356-1358

Checkley DM, Entzeroth LC (1985) Elemental and isotopic fractionation of carbon and nitrogen by marine planktonic copepods and implications to the marine nitrogen cycle. J Plankton Res 7:533-568

Deniro MJ, Epstein S (1981) Influence of diet on the distribution of nitrogen isotopes in animals. Geochim Cosmochim Acta 45:341-353 
Engström J, Koski M, Viitasalo M, Reinikainen M, Repka S, Sivonen K (2000) Feeding interactions of the copepods Eurytemora affinis and Acartia bifilosa with the cyanobacteria Nodularia sp. J Plankton Res 22:1403-1409

Fenchel T (1988) Marine plankton food chains. Annu Rev Ecol Syst 19:19-38

Hoppe GH (1981) Blue-green algae agglomeration in surface water: a microbiotope of high bacterial activity. Kiel Meeresforsch Sonderh 5:291-303

Howarth RW, Marino R (1988) Nitrogen fixation in freshwater, estuarine and marine ecosystems. 2. Biogeochemical controls. Limnol Oceanogr 33:688-701

Kaehler S, Pakhomov EA, McQuaid CD (2000) Trophic structure of the marine food web at the Prince Edward Islands (Southern Ocean) determined by $\delta^{13} \mathrm{C}$ and $\delta^{15} \mathrm{~N}$ analysis. Mar Ecol Prog Ser 208:13-20

Karl R, Letelier L, Tupas L, Dore J, Christian J, Hebel D (1997) The role of nitrogen fixation in biogeochemical cycling in the subtropical North Pacific Ocean. Nature 388:533-538

Kononen K, Nömmann S (1992) Spatio-temporal dynamics of the cyanobacterial blooms of the Gulf of Finland, Baltic Sea. In: Carpenter EJ (ed) Marine pelagic cyanobacteria: Trichodesmium and other diazotrophs. Kluwer Press, London, p 95-113

Koski, M, Schmidt K, Engström-Ost J, Viitasalo M, Jónasdóttir SH, Repka S, Sivonen K (2002) Calanoid copepods feed and produce eggs in the presence of toxic cyanobacteria Nodularia spumigena. Limnol Oceanogr 47:878-885

Kozlowsky-Suzuki B, Karjalainen M, Lehtiniemi M, Engström-Öst J, Koski M, Carlsson P (2003) Feeding, reproduction and toxin accumulation by the copepods Acartia bifilosa and Eurytemora affinis in the presence of the toxic cyanobacterium Nodularia spumigena. Mar Ecol Prog Ser 249:237-249

Larsson U, Hajdu S, Walve J, Elmgren R (2001) Baltic Sea nitrogen fixation estimated from the summer increase in upper mixed layer total nitrogen. Limnol Oceanogr 46: 811-820

Letelier RM, Karl DM (1996) Role of Trichodesmium spp. in the productivity of the subtropical North Pacific Ocean. Mar Ecol Prog Ser 133:263-273

Lindfors V, Joffre SM, Damski J (1993) Meteorological variability of the wet and dry deposition of sulphur and nitrogen compounds over the Baltic Sea. Water Air Soil Pollut 66:1-28

Mauchline J (1998) The biology of calanoid copepods. In: Blaxter JHS, Southward AJ, Tyler PA (eds) Advances in marine biology, Vol 33. Academic Press, San Diego, CA

Meyer-Harms B, Reckermann M, Voss M, Siegmund H, Von

Editorial responsibility: Otto Kinne (Editor-in-Chief), Oldendorf/Luhe, Germany
Bodungen B (1999) Food selection by calanoid copepods in the eutrophic layer of the Gotland Sea (Baltic Proper) during mass occurrence of $\mathrm{N}_{2}$-fixing cyanobacteria. Mar Ecol Prog Ser 191:243-250

Minagawa M, Wada E (1984) Stepwise enrichment of ${ }^{15} \mathrm{~N}$ along food chains: further evidence and the relation between $\delta^{15} \mathrm{~N}$ and animal age. Geochim Cosmochim Acta 48:1135-1140

Montoya JP, Carpenter EJ, Capone DG (2002) Nitrogen fixation and nitrogen isotope abundances in zooplankton of the oligotrophic North Atlantic. Limnol Oceanogr 47: $1617-1628$

O'Neil JM, Metzler PM, Glibert PM (1996) Ingestion of ${ }^{15} \mathrm{~N}_{2}$-labelled Trichodesmium spp. and ammonium regeneration by the harpacticoid copepod Macrosetella gracilis. Mar Biol 125:89-96

Owens NJP (1987) Natural variations in ${ }^{15} \mathrm{~N}$ in the marine environment. Adv Mar Biol 24:389-451

Redfield AC (1958) The biological control of chemical factors in the environment. Am Sci 46:205-221

Rolff C (2000) Seasonal variation in $\delta^{13} C$ and $\delta^{15} \mathrm{~N}$ of size-fractionated plankton at a coastal station in the northern Baltic proper. Mar Ecol Prog Ser 203:47-65

Sellner KG (1997) Physiology, ecology, and toxic properties of marine cyanobacteria blooms. Limnol Oceanogr 42: $1089-1104$

Sellner KG, Olson MM, Kononen K (1994) Copepod grazing in a summer cyanobacteria bloom in the Gulf of Finland. Hydrobiologia 292/293:249-254

Sellner KG, Olson MM, Olli K (1996) Copepod interactions with toxic and non-toxic cyanobacteria from the Gulf of Finland. Phycologia 35:177-182

Sommer F, Saage A, Santer B, Hansen T, Sommer U (2005) Linking foraging strategies of marine calanoid copepods to patterns of nitrogen stable isotope signatures in a mesocosm study. Mar Ecol Prog Ser 286:99-106

Sommer U, Sommer F, Santer B, Jamieson C, Boersma M, Becker C, Hansen T (2001) Complementary impact of copepods and cladocerans on phytoplankton. Ecol Lett 4: $545-550$

Utermöhl H (1958) Zur Vervollkommnung der quantitativen Phytoplankton-Methodik. Mitt Int Ver Theor Angew Limnol 9:1-38

Wasmund N, Nausch G, Schneider B, Nagel K, Voss M (2005) Comparison of nitrogen fixation rates determined with different methods: a study in the Baltic Proper. Mar Ecol Prog Ser 297:23-31

Zehr JP, Ward BB (2002) Nitrogen cycling in the ocean: new perspectives on processes and paradigms. Appl Environ Microbiol 68:1015-1024

Submitted: January 21, 2006; Accepted: March 13, 2006

Proofs received from author(s): September 27, 2006 